Egyptian Journal of Aquatic Biology \& Fisheries

Zoology Department, Faculty of Science,

Ain Shams University, Cairo, Egypt.

ISSN $1110-6131$

Vol. 23(5): 169 - 182 (2019)

www.ejabf.journals.ekb.eg

\title{
Ocean acidification impact on the grooved carpet shell clam (Ruditapes decussatus)
}

\section{Merna E. Awad ${ }^{1}$, Nayrah A. Shaltout ${ }^{2}$, Fedekar F. Madkour ${ }^{1}$, Mohamed A. Abu El-Regal', Heba S. El-Sayed*3, Eman El-Wazzan ${ }^{3}$ \\ 1- Marine Science Department, Faculty of Science, Port Said University, Port Said, Egypt}

2- Marine Chemistry Department, National Institute of Oceanography and Fisheries, Alexandria, Egypt

3- Aquaculture Division, National Institute of Oceanography and Fisheries, Alexandria, Egypt

* Corresponding author : hebasaad2222@yahoo.com

\section{ARTICLE INFO}

Article History:

Received: May 2, 2019

Accepted: Nov. 28, 2019

Online: Dec. 2019

\section{Keywords:}

Ocean acidification grooved carpet clam Ruditapes decussatus Calcifying organism Biological impact Mortality

\section{ABSTRACT}

The grooved carpet shell clam (Ruditapes decussatus) is one of the most economicallyimportant mollusks inhabiting Mediterranean lagoons and sandy beaches both from fisheries and aquaculture. The present study aims to study the impact of different levels of acidification on this calcifying organism. Juvenile clams (avg. Shell Length, $\mathrm{SL}=23.22 \pm 0.84 \mathrm{~mm}$ ) were incubated in $\mathrm{CO}_{2}$ enriched seawater at four different $\mathrm{CO}_{2}$ concentrations [420 ppm (ambient control), 550 ppm, $750 \mathrm{ppm}$ and $1050 \mathrm{ppm}$ ] representing projected atmospheric $\mathrm{CO}_{2}$ concentration scenarios for the year 2100 by IPCC. The studied biological parameters showed slight decrease with increasing $\mathrm{pCO}_{2}$. However, differences were not significant. Standard length decreased as $\mathrm{pCO}_{2}$ concentration increased, with a maximum average decrease of $(-0.12)$ recorded at $750 \mathrm{ppm}$ as compared to the control group. Regarding total weight, the decrease was highest $(-0.10)$ in both 550 and $1050 \mathrm{ppm}$. Moreover, clams kept at $550 \mathrm{ppm}$ showed the lowest condition index $(11.40 \pm 1.49)$ and highest mortality rate of $8 \%$. The study of physiological response showed increase in metabolic rate and ammonia excretion in both $550 \mathrm{ppm}$ and the control 420 ppm groups. Algal feed clearance rate decreased with increasing acidification with highest value in the control $(420 \mathrm{ppm})$ group and lowest average value of $3.34 \mathrm{1} / \mathrm{h}^{-1}$ in the extremely high $\mathrm{pCO}_{2}(1050 \mathrm{ppm})$ group. By the end of century, ocean acidification may exert additional stress on the health of $R$. decussatus and its economic value.

\section{INTRODUCTION}

Ocean acidification is the reduction of $\mathrm{pH}$ in the seawater due to the increased levels of atmospheric $\mathrm{CO}_{2}$. At a quickened rate, the $\mathrm{CO}_{2}$ deposition into the atmosphere has been increased since the industrial revolution (beginning in the 1750s). The increases in atmospheric carbon dioxide partial pressure $\left(\mathrm{pCO}_{2}\right)$, and different greenhouse gases have been given a share in global warming. The Current average atmospheric $\mathrm{pCO}_{2}$ of approximately $400 \mathrm{ppm}$ is higher than the highest $\mathrm{pCO}_{2}$ over the past 2.1 million years (approximately 300 ppm; Hönisch et al. 2009). According to the Intergovernmental Panel on Climate Change's (IPCC) B1 scenario 
(stabilized population growth by 2050 and a more service- and information-driven economy), proposed average global $\mathrm{CO}_{2}$ emissions will attain $650 \mathrm{ppm}$ by 2100 (Caldeira and Wickett 2005). Following Henery's law, the increase in atmospheric $\mathrm{pCO}_{2}$ will result in an increase in its concentration in an adjacent water body as a result of physical dissolution through the surface microlayer. About a quarter of the $\mathrm{CO}_{2}$ produced daily by human activities is being absorbed by the oceans, causing ocean acidification which results from changing the seawater carbonate system chemical equilibrium. The dissolution of $\mathrm{CO}_{2}$ in oceans causes increase in acidity (decrease in $\mathrm{pH}$ ) and reduction in the obtainable carbonate ions $\left(\mathrm{CO}_{3}{ }^{2-}\right)$, and consequently become increasingly shallower under saturation horizon of $\mathrm{CaCO}_{3}$ (Feely et al., 2004, 2012), which is projected to become more persistent and widespread by 2050 and beyond, (Gruber et al, 2012). If population growth occurs at a higher rate accompanied by slow economic development and limited technological changes (IPCC's A2 scenario), emissions will likely reach 970 ppm by 2100 (Caldeira and Wickett 2005). Ocean acidification is expected to affect ecosystems at an accelerating pace over the next century (Caldeira and Wickett 2003; IPCC 2007).

$\mathrm{CaCO}_{3}$ is required by marine organisms as the main building blocks of their skeletons, shells and other calcareous frames. In 250 years, Ocean acidity has increased by $30 \%$, which is equivalent to a decreasing of surface seawater $\mathrm{pH}$ of 0.1 units (Orr et al., 2005), therefore, the proposed scenarios by 2100 could be tripled.

$\mathrm{pH}$ has a vital role in all marine organisms and the change in internal $\mathrm{pH}$ can affect an organism's health or even lead to death. Marine organisms have to preserve their internal $\mathrm{pH}$ prorated to that of the surrounding seawater. Some have complicated systems that can regulate internal $\mathrm{pH}$. The most heavily influenced species by their surrounding environment are the ones without these systems and can be rapidly menaced by changes in acidity. Although the research concerned with the impact of ocean acidification on marine environment is growing very fast, still poorly understood and the picture is not fully clear. However, few studies identified some marine organisms that can be threatened by changing the environment (Gazeau et al., 2007; Beniash et al., 2010; Michaelidis et al., 2005; Thomsen and Melzner, 2010, Ibrahim et al., 2014, Khairy et al., 2014).

The carpet shell clam Ruditapes decussatus is rated as one of the most popular bivalves with a high economic value in many countries (Chessa et al. 2005; PradoAlvarez et al., 2009; Lucrezia et al. 2011). It is intended as an auspicious candidate for the emerging bivalve aquaculture progression in Egypt (El-Wazzan et al. 2012; Abbas et al. 2018). The present study aims to study the impact of different levels of acidification on this calcifying organism.

\section{MATERIALS AND METHODS}

\section{Study organism collection}

The grooved carpet shell clam Ruditapes decussatuswas was collected in November 2017 from the Lake Timsah in Ismailia, Egypt, which is located on the Suez Canal at $30^{\circ} 34^{\prime} \mathrm{N}$ and $32^{\circ} 18^{\prime} \mathrm{E}$. Clams of experiments were transported and placed in the receiving tank to recover from the transportation stress and acclimate to lab conditions in wet laboratories at the National Institute of Oceanography and Fisheries - Alexandria, Egypt. The mean length at the start of the study was 23.22 mm $( \pm 0.84$ SD).

\section{Experimental design}


The experimental design was composed of four treatments representing different $\mathrm{PCO}_{2}(420 \mathrm{ppm}, 550 \mathrm{ppm}, 750 \mathrm{ppm}, 1050 \mathrm{ppm})$. After two days of acclimation, clams were housed in $3 \mathrm{~L}$ of $1 \mu \mathrm{m}$ filtered seawater in 4 -liter tanks. The experiment was running in two sets A and B with exactly the same condition. Each set was composed of 12 experimental tanks ( 3 replicate tanks per each $\mathrm{PCO}_{2}$ treatment). Each tank had an air pump for providing oxygen for healthy circulation system. Set A was used to measure metabolic rate, clearance rate and ammonia excretion, while set B had been set up for mortality recording, shell length, total weight and condition index measurements .

Clams were fed with Isochrysis galbana at concentration of 100,000 cell/ml once daily. Clams were incubated for a period of 36 days at the four $\mathrm{pCO}_{2}$ concentrations mentioned above keeping alkalinity constant.

\section{Seawater chemistry manipulation}

Seawater was adjusted to the four $\mathrm{CO}_{2}$ concentrations $\{420 \mathrm{ppm}$ (ambient control), $550 \mathrm{ppm}, 750 \mathrm{ppm}$ and $1050 \mathrm{ppm}$ \} and the corresponding $\mathrm{pH}$ 's by mixing with $\mathrm{CO}_{2}$ saturated sea water while keeping alkalinity constant by using the seacarb package within $\mathrm{R}$ program. This $\mathrm{CO}_{2}$ saturated seawater was acidified through bubbling of $1 \mu$ filtered sea water with pure $\mathrm{CO}_{2}$ gas till saturation. This design for acidification experiment manipulation had declared the best way to manipulate the $\mathrm{pCO}_{2}$ at constant alkalinity.

Seawater sampled for the initial $\mathrm{pH}$ was measured by $\mathrm{pH}$ meter (Jenway 3505). The $\mathrm{pH}$ electrode was calibrated with TRIS buffer on a total (T) scale following Dickson et al. (2007). Total alkalinity (TA) was measured following Sarazin et al. (1999). Certified reference materials (CRM batch 115) were used to calibrate and establish correction factors for TA measurements that were obtained from Professor Andrew Dickson at the Marine Physics Laboratory of the Scripps Institute of Oceanography, University of California, San Diego. Seawater temperature, salinity, silicate and phosphate were measured spectrophotometry according to Grasshoff et al. (1983) and used as an input for $\mathrm{CO}_{2}$ sys calculations.

Seawater carbonate chemistry parameters in the beginning of the experiment and throughout it were determined via calculations by $\mathrm{CO}_{2} \mathrm{SYS}$ using the two measured $\mathrm{CO}_{2}$ parameters, $\mathrm{pH}_{\mathrm{sw}}$ and $\mathrm{TA}_{\mathrm{sw}}$. Regarding the carbonate system, dissociation constants K1 and K2 (Mehrbach et al., 1973, refitted by Dickson and Millero, 1987) were used. The acidity constant of the $\mathrm{H}_{2} \mathrm{SO}_{4}$ in seawater was calculated using the constants of Dickson (1990).

Water chemistry in each system was replaced daily, monitored and adjusted every 2 hours using carbon dioxide saturated Seawater.

\section{Biometrics measurements}

\section{Shell length and total weight:}

Shell lengths of 360 individuals (30 individuals per replicate jar x 3 replicates for each of 4 treatments: $30 \times 3 \times 4=360$ ) were measured initially and at the end of the experiment using a Vernier caliper to $0.1 \mathrm{~mm}$. In clams, the length corresponds to the anterior/posterior axis and is measured perpendicularly from the height line, matching the dorsal/ventral axis. Weights of the same group were also measured using four decimals \pm 0.0002 ordinary laboratory balance.

\section{Condition index (C.I):}

A day before setting up the experiment, condition index (C.I) was determined for 50 individuals in pre-weighted pans. The measurements of C.I. were repeated at 
the end of the experiment for 30 individuals per treatment and its triplicate, the clams were dissected after their shell length and total weight had been recorded, they were opened by cutting the adductor muscle, the shell and viscera were entirely separated in their own weighed pans, both were dried in separate pans at $90^{\circ} \mathrm{C}$ for $24 \mathrm{~h}$, then they were weighed again. C.I was calculated according to (Walne 1976) as follows, C.I $=[($ dry flesh weight/ dry shell weight $) \times 100]$.

Mortality:

Mortality was daily recorded by counting dead and gapping (diying) clams after which they were removed from the jars and their shell lengths measured and recorded by date.

\section{Physiological measurements}

\section{Metabolic rate:}

Metabolic rate was calculated by measuring oxygen consumption rate (OCR) by incubating one clam per jar from each treatment in $250 \mathrm{~mL}$ oxygen bottle for $3 \mathrm{~h}$. Clams were not fed for a period of $6 \mathrm{~h}$ before the start of the incubations. Oxygen consumption rates were estimated as the rate of oxygen concentrations decrease over the $3 \mathrm{~h}$ incubations as measured according to the modified Winkler method for initial and after $3 \mathrm{~h}$ incubation time. OCR was calculated using the following equation (Cerezo Valverde et al. 2006):

$\mathrm{OCR}=\left(\mathrm{DO}_{0}-\mathrm{DO}_{\mathrm{t}}\right) \mathrm{V} /(\mathrm{DW} \mathrm{T})$

The initial and final concentrations of dissolved oxygen (DO) are denoted by subscripts 0 and time respectively, $\mathrm{V}$ is the volume of respiration chamber (1), DW is the dry weight of $\mathrm{R}$. decussates, and $\mathrm{T}$ is the time between the initial and final measurements (h).

\section{Clearance rate:}

Clearance rate was determined through the volume of water cleared of particles per unit time, and it can be determined indirectly by monitoring the decline in algal cells in a "closed system". After allowing 5 minutes for the algal cells to mix thoroughly. A sample of $10 \mathrm{ml}$ was taken from the center of each jar with a $10-\mathrm{mL}$ pipette. Samples were collected after 2 hours. The cell concentrations were counted immediately using an electronic particle counter Coulter Counter® Model ZM or D, fitted with a $140 \mu \mathrm{m}$ aperture tube. Cell concentrations were the mean of 3 to 4 counts. Clearance rate was calculated using the equation (Coughlan, 1969):

$\mathrm{CR}=\mathrm{V}\left(\ln \mathrm{C}_{1}-\ln \mathrm{C}_{2}\right) / \mathrm{t}$

Where: $C R$ is the clearance rate, $V$ is the volume of water used, $C_{1}$ and $C_{2}$ are the cell concentrations between two sampling times, and $\mathrm{t}$ is the time increment.

\section{Ammonia excretion rate:}

The experiment was conducted by placing 30 adult clams ( $6 \mathrm{~g}$ dry weight) in $3 \mathrm{~L}$ of seawater and monitoring the ammonia concentration initially and 24 hours after feeding with I. galbana. This analysis was performed according to methods described by Grasshoff et al. (1983).

\section{Statistical analysis:}

All statistical analyses were performed using SPSS (version 22). Paired T- test has been performed to declare the differences between before and after the experiment in both shell length and total weight of the studied clams. Moreover, a one-way ANOVA was performed with treatment as a single factor to determine differences among treatments (different acidification levels) and effect of time post exposure on different indices of clam physiological responses. 
Mean size of clams used in the present study was $\mathrm{SL}=23.22 \mathrm{~mm} \pm 0.84 \mathrm{SD}$. $\mathrm{pH}$ of the ambient control represented by $\mathrm{PCO}_{2}$ of 420 was about $8.12 \pm 0.06$, and for those representing ocean acidification conditions of $550 \mathrm{ppm}, 750 \mathrm{ppm}$ and $1050 \mathrm{ppm}$ were $7.98 \pm 0.05,7.84 \pm 0.04$ and $7.62 \pm 0.06$ respectively.

The impact of ocean acidification on shell length:

Comparing different $\mathrm{PCO}_{2}$ treatments, Ruditapes decussatus showed no significant changes in their shell length between SL before the start and at the end of the experiment $(\mathrm{P} \geq 0.05$; Paired $\mathrm{t}$ - test in each treatment) with no significant differences in SL among all treatments including the control after exposure to different acidification levels (ANOVA shown in Table 1).

The impact of ocean acidification on total weight:

Total weight had insignificant decrease amongst different treatments $(\mathrm{P} \geq 0.05$; Table 1) after 36 days of acidification experiment at different $\mathrm{pCO} 2$ concentrations. Paired t-test showed that there were significant differences between total before and after the experiment for both treatments 550 and $1050 \mathrm{ppm}(\mathrm{P}=0.024$ and 0.002 , respectively).

Table 1: One-way ANOVA testing the biological and physiological parameters in Ruditapes decussates clams exposed to different acidification conditions ( $\mathrm{pCO}_{2}=420,550,750$ and $\left.1050 \mathrm{ppm}\right)$.

\begin{tabular}{lrrr}
\hline Source & df & \multicolumn{1}{c}{ F } & \multicolumn{1}{c}{ Sig. } \\
\hline Shell length & 3 & 1.226 & 0.300 \\
Total weight & 3 & 3.809 & 0.010 \\
Condition Index & 4 & 23.299 & 0.000 \\
Metabolic Rate (concentration) & 3 & 0.445 & 0.723 \\
Metabolic Rate intervals (TIMES) & 8 & 7.122 & 0.000 \\
Clearance Rate (concentration) & 3 & 0.681 & 0.572 \\
Clearance Rate intervals (TIMES) & 7 & 3.818 & 0.006 \\
Ammonia Excretion (concentration) & 3 & 1.349 & 0.326 \\
Ammonia Excretion intervals (TIMES) & 3 & 4.1 & 0.051 \\
\hline
\end{tabular}

The impact of ocean acidification on condition index:

Condition index values decreased in all treatments compared to the initial values of the stock (Fig. 1).

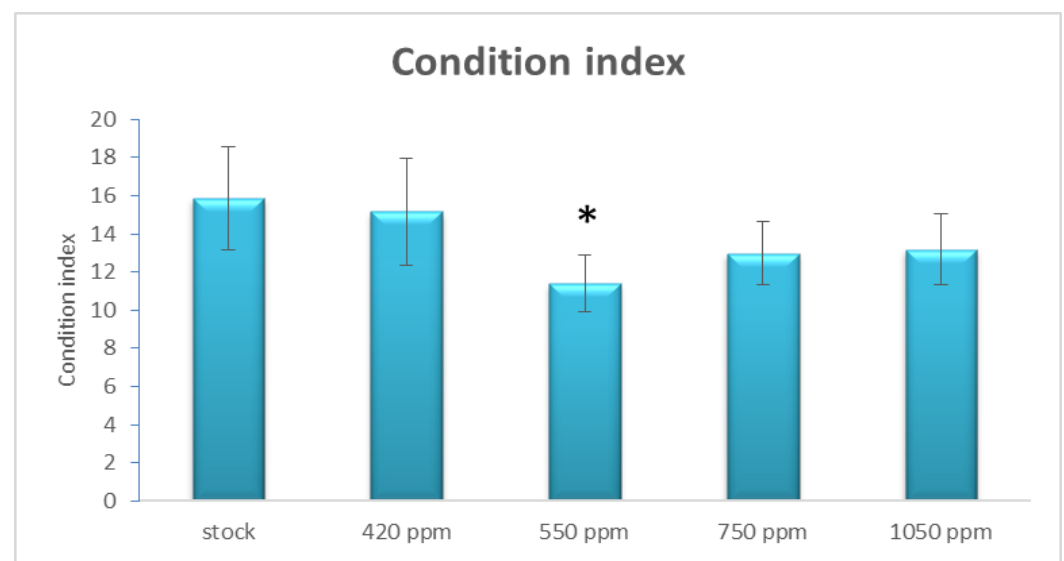

Fig. 1: Mean condition index $(\mathrm{gDW} \pm \mathrm{SD})$ of Ruditapes decussatus exposed to different ocean acidification conditions represented by different $\mathrm{pCO}_{2}$ (420 ppm (ambient control), $550 \mathrm{ppm}$, $750 \mathrm{ppm}$ and $1050 \mathrm{ppm}$ ) for 36 days experiment. Asterisk (*) represent significant difference.

Result showed that the lowest condition index of $11.40 \pm 1.49$ was observed in the $550 \mathrm{ppm}$ treatment, while the ambient control group showed C.I value of $15.17 \pm$ 2.80. Condition index had significant differences among different treatments $(\mathrm{P}<$ 0.05 ; Table 1). 
The impact of the ocean acidification on clam mortality:

No significant effect of ocean acidification was observed on clam mortality. Mortality of Ruditapes decussatus incubated clams at $550 \mathrm{ppm}$ had highr mortality of $8 \%$ compared to the ambient group (3\%) which is not significant in both cases. No other high mortalities occurred in any of the treatments (Fig. 2).

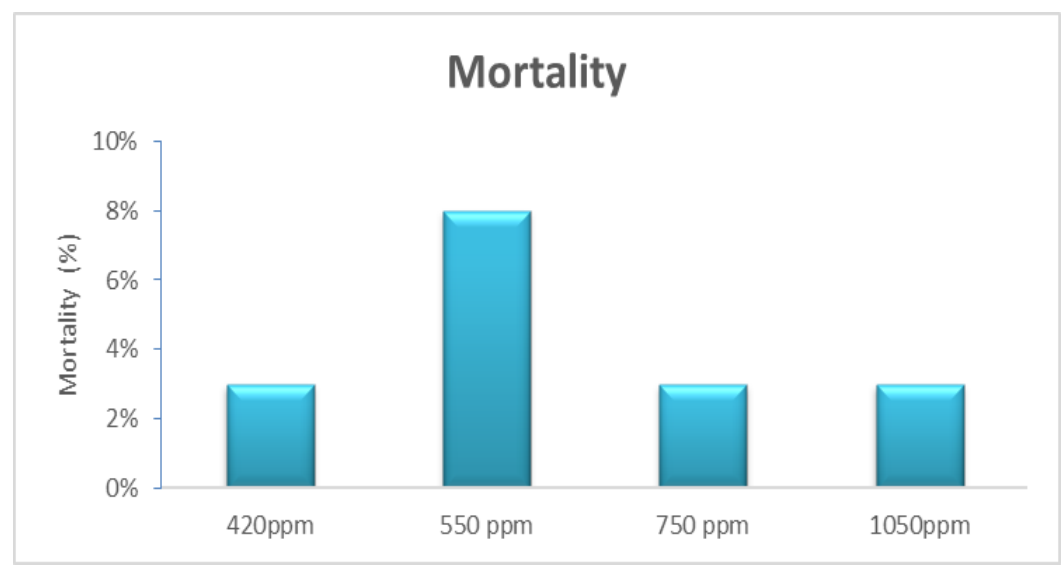

Fig. 2. Mortality (\%) of Ruditapes decussatus exposed to different ocean acidification conditions represented by different $\mathrm{pCO}_{2}$ (420 ppm (ambient control), $550 \mathrm{ppm}, 750 \mathrm{ppm}$ and $1050 \mathrm{ppm}$ ) for 36 days' experiment.

\section{The impact of the ocean acidification on metabolic rate:}

In calculating oxygen consumption rate, a high metabolic rate was observed at the beginning of the experiment in all treatments (Fig. 3). Metabolic rates fluctuated throughout the experimental duration but in general was lower than initial value. However, It did not show significant difference amongh different groups (Table 1). Briefly; following the metabolic rate over the experimental time intervals, metabolic rates of clams were lower than initial values after 5 days and 9, 31 and 36 days as compared to initial values (Fig. 3). Time post exposure to different acidification levels had significant impact on metabolic rate in clams $(\mathrm{P}=0.000)$.

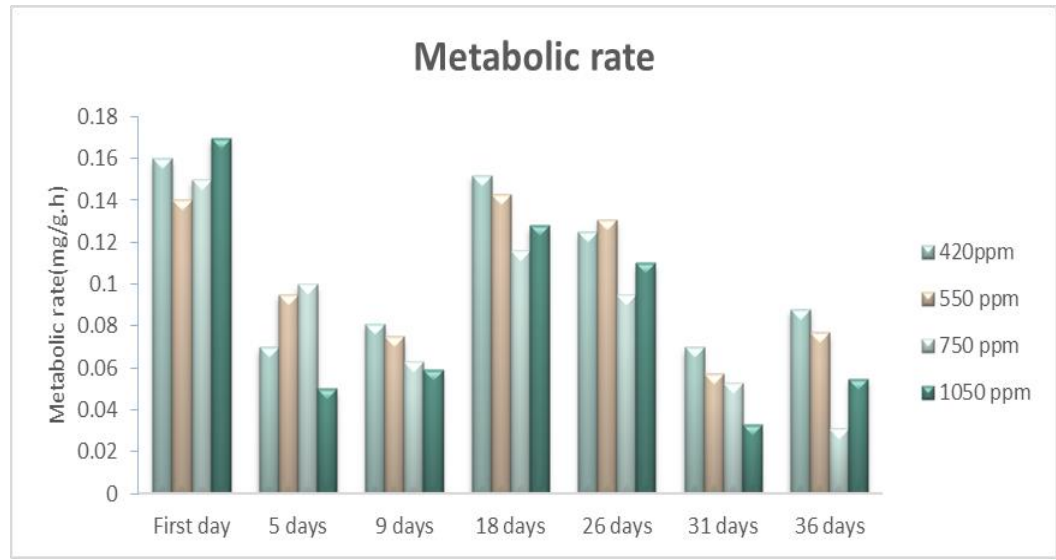

Fig. 3. Metabolic rate of clam (Ruditapes decussatus) batch (A) under different acidification conditions $\left(\mathrm{pCO}_{2}=420,550,750\right.$ and $\left.1050 \mathrm{ppm}\right)$.

The impact of the ocean acidification on clearance rate:

The algae clearance rates by Ruditapes decussatus, at different acidification concentration, showed no significant differences among treatments (Table 1). Increasing the time of exposure to acidification showed significant differences among 
time intervals $(\mathrm{P}=0.006)$. Clams incubated at $\mathrm{pCO}_{2}(1050 \mathrm{ppm})$ showed the lowest clearance, while the highest clearance rate was recorded by the ambient group $\mathrm{pCO}_{2}$ (420 ppm; Fig. 4).

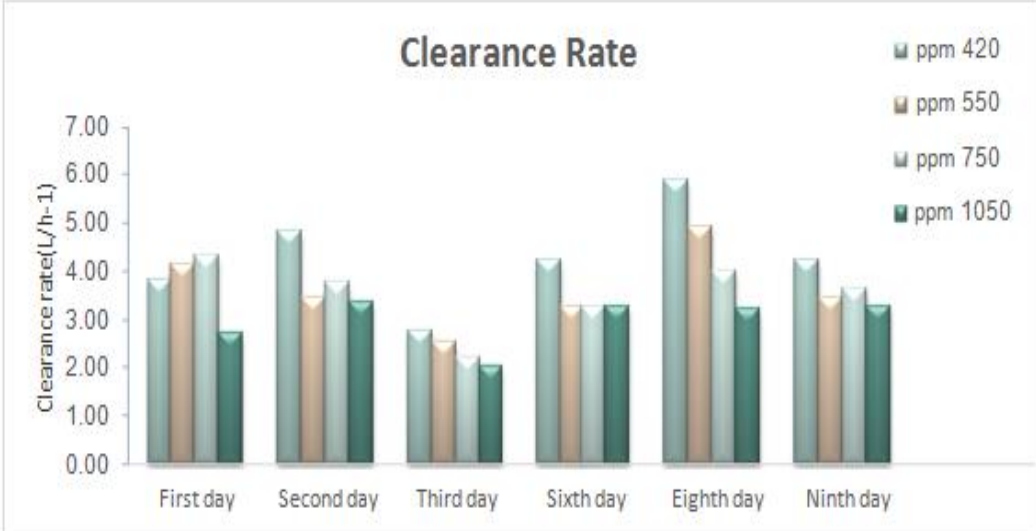

Fig. 4: Clearance rate ofalgae by Ruditapes decussatus under different acidification conditions $\left(\mathrm{pCO}_{2}=\right.$ $420,550,750$ and $1050 \mathrm{ppm})$.

\section{The impact of the ocean acidification on Ammonia excretion:}

Ammonia excretion determination showed that the highest ammonia concentration was recorded in the groups of $420 \mathrm{ppm}$ ambient control and $550 \mathrm{ppm}$, while the lowest ammonia concentration was recorded in the $1050 \mathrm{ppm}$ group (Fig. 5). However, ANOVA test recorded no significant differences between different groups (Table 1). Moreover, ANOVA cleared that there was a significant effect of time of exposure to acidification $(\mathrm{P}=0.05$; Table 1$)$.

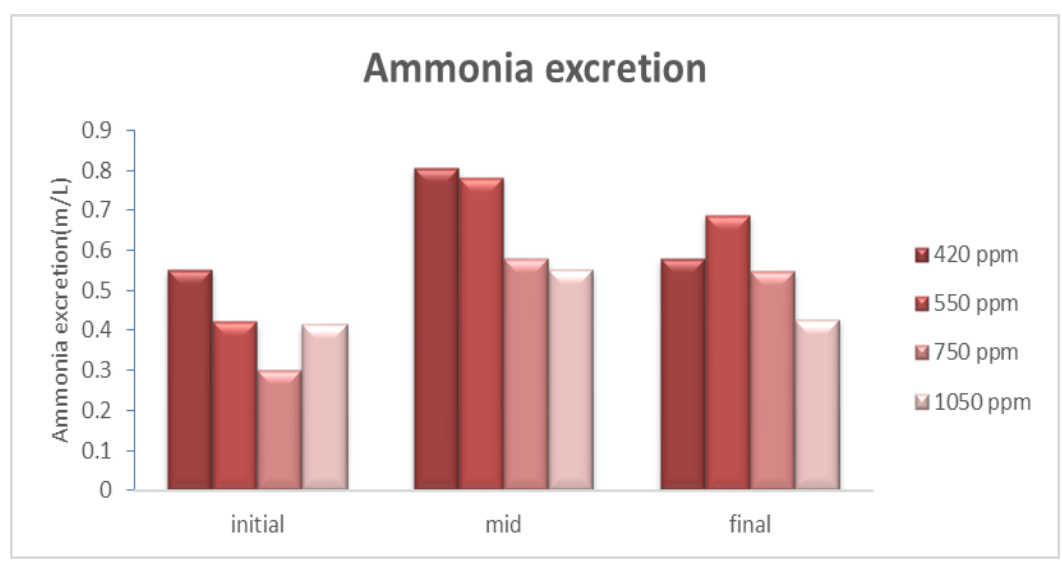

Fig. 5: Ammonia excretion of Ruditapes decussatus under different acidification conditions $\left(\mathrm{pCO}_{2}=\right.$ 420, 550, 750 and $1050 \mathrm{ppm})$.

\section{DISCUSSION}

The present study is focused on the effect of ocean acidification on the Mediterranean clam Ruditapes decussatus which is rated as one of the most commercially important and highly economic bivalve in many countries including Egypt (FAO 2018; Abbas et al. 2018). This is due to increasing consumer demand and significance for potential aquaculture of bivalve in Egypt.

As the assent within the ocean acidification field escalates by time, the impacts of lowered seawater $\mathrm{pH}$ are hugely affecting the energy distribution requirements of the clams, as more energy is needed for the conservation processes of the 
physiological balance (Wood et al. 2008, Thomsen and Melzner 2010, Stumpp et al. 2011, Pan et al. 2015).

Studies that examined bivalve's responses to ocean acidification showed that adult bivalves are mostly less sensitive to changes in oceanic $\mathrm{pCO}_{2}$ than the larval stages, but they still display changes in growth, calcification, and physiological responses (Dupont et al., 2010). Bivalve shell deposition is negatively impacted by elevated $\mathrm{pCO}_{2}$ (Gazeau et al., 2007), and some studies have illustrated decreased shell growth in low pH-exposed juveniles and adults (Beniash et al., 2010; Michaelidis et al., 2005; Thomsen and Melzner, 2010).

\section{The impact of the ocean acidification on biometric measurements:}

Growth of marine organisms is a physiological process which becomes significantly slower under long-term exposure of increased $\mathrm{CO}_{2}$ levels (Michaelidis et al., 2005).

Some studies have shown a link between $\mathrm{pH}$ conditions and bivalve growth rates. Researches are pointing to the inhibiting effect of ocean acidification on the growth of different species of bivalve (Michaelidis et al., 2005, Berge et al., 2006). For example, (Shirayama and Thornton, 2005) found that even very average increases in $\mathrm{CO}_{2}$ of $200 \mathrm{ppm}$ above present levels lead to reduction in the growth rate and the survival rate of echinoderms and gastropods, indicating that long-term of exposure to $\mathrm{CO}_{2}$ changes can affect the growth of calcifying organisms.

Bressan et al. (2014) found that under acidified conditions, the Chamelea gallina did not grow, but their live weight decreased greatly and a slight reduction in shell length was even observed.

In the present study, the impact of increased $\mathrm{CO}_{2}$ on growth is represented in terms of shell length and weight. SL changes showed a slight insignificant reduction in shell size. Similarly, experiments on juvenile Veneridae (Venus clam) have not shown any significant difference in growth which is measured as size, weight and net calcification (Range et al., 2011, Talmage and Gobler, 2011). Moreover, the studies on Mytilus edulis (Melzner et al. 2011) showed no significant $\mathrm{CO}_{2}$ effect to shell mass and length. The studies of the impact acidification on shell length and shell weight of Mytilus galloprovincialis (Gazeau et al., 2014) did not appear to be highly sensitive to ocean acidification. Similar recorded results on the clamMercenaria mercenaria were explained as a result of shell erosion (Ringwood and Keppler, 2002).

Regarding the recorded total weight during the current experiment, results showed no positive growth was recorded in terms of total live weight in the clams, with no significant differences being detected between the control and treated animals. Other studies described that growth might be significantly reduced under medium and long-term exposure to elevated $\mathrm{pCO}_{2}$ levels in mussel Mytilus chilensis (Navarro et al., 2013; Duarte et al., 2014). Moreover, both shell and soft tissue growth of the oyster $C$. virginica were reduced when exposed to high $\mathrm{pCO}_{2}$ levels $(\mathrm{pH} 7.5$; Beniash et al., 2010).

The recorded results in the current study of the C.I. values decreased throughout all treatments compared to the ambient control group. Result showed the lowest condition index $(11.40 \pm 1.49)$ at $550 \mathrm{ppm}$, compared to the control group (15.17 \pm $2.80)$ that was approximately unchanged from the stock. The high condition values are good indicators for nutrient reserves accumulation for total weight growth in bivalves (Filgueira et al. 2013). The lowest recorded condition index (C.I) occurd at 550ppm $\mathrm{CO}_{2}$ where it is consistent with the highest mortality observation. This may explain the observed lower energy allocation to growth under $\mathrm{pCO}_{2}$ conditions (550 and 1050ppm). 
Mortality (\%) of clam Ruditapes decussatus in the present study showed a maximum mortality of $8 \%$ recorded at $550 \mathrm{ppm}$ and delayed mortality at higher $\mathrm{pCO}_{2}$ (750 and $1050 \mathrm{ppm}$ ). This could be explained according to the hypothesis of Gazeau et al. ( 2014) by which exerting metabolic depression $\mathrm{CO}_{2}$ can alleviate the level of stress and delay mortality through more efficient exploitation of energy reserved and passive tolerance as an adaptation strategy. This is achieved through more efficient imposition of energy reserves and passive tolerance. Therefore, the results of the current study showed low metabolic rate and low mortality rate recorded at both treatments (750 and $1050 \mathrm{ppm}$ ), whereas group $550 \mathrm{ppm}$ showed higher mortality $(8 \%)$ as they had high metabolic rate relative to the ambient control group.

\section{The impact of the ocean acidification on physiological responses:}

Several studies have described metabolic depression in different species of marine organisms at elevated $\mathrm{pCO}_{2}$ concentrations as caused by the low capacity to compensate for disturbances in extracellular ion and acid-base status (Michaelidis et al., 2005; Pörtner, 2008). This is in agreement with the results of the present study, where the oxygen uptake was depressed at 750 and $1050 \mathrm{ppm} \mathrm{CO}_{2}$ as compared to the control seawater. A depression in the metabolism caused by the un neutralized acidbase status and produce "trade-off" in energy budget in many species. This adaptation strategy is utilized to match Adenosine triphosphate supply and Adenosine triphosphate demand and thus extend their survival (Melatunan et al 2013). On the other hand, the clams under 550ppm $\mathrm{CO}_{2}$ showed high metabolic rate associsated with to the highest mortality as explained previously. However, this was referred to as an increase in food absorption efficiency (Fernández-Reiriz et al., 2012). FernándezReiriz et al. (2011)reported similar results for the specific rate of oxygen consumption by juveniles of the clam $R$. decussatus, with lower values in individuals exposed to high levels of $\mathrm{pCO}_{2}$ with $(\Delta \mathrm{pH}-0.7)$.

Considering the impact of sea water acidification on clams feeding, the results showed a pronounced decrease in the clearance rate at the highest $\mathrm{pCO}_{2}$ level $(1050$ $\mathrm{ppm}$ ) corresponding to $\mathrm{pH}$ of (7.62). The negative effect of increasing $\mathrm{pCO}_{2}$ on the feeding rate of $R$. decussatus observed in the present study had also been recorded for the same species (Bamber 1987; Fernandez-Reiriz et al. 2011). Fernandez-Reiriz et al. (2011) observed a reduction in the feeding rate in the clam Ruditapes decussatus at the highest experimental $\mathrm{pCO}_{2}$ equivalent to $\mathrm{pH}$ 7.48. Similarly, according to Bamber (1987), the feeding activity of the clam $R$. decussatus is inhibited at $\mathrm{pH}<7.0$, and both, tissue and shell growths were significantly reduced. Bamber (1990) also described a negative effect of seawater acidification on the feeding activity and growth of the bivalves Ostrea edulis. Results of the present study may be explained by indicating possible deficiencies in the functioning of the digestive systems under conditions of seawater acidification which is synergized with metabolic decline, where the oxygen uptake decreased at elevated $\mathrm{pCO}_{2}$ levels with high $\mathrm{pCO}_{2}$ levels in the seawater(Navarro et al., 2013).

Several studies reported low ammonia excretion (AE) of marine bivalves with elevated $\mathrm{pCO}_{2}$ levels (Bayne and Newell, 1983; Velasco and Navarro, 2005). Considering the impact of seawater acidification on clam ammonia Excretion (AE), Wang et al. (2015) observed low values for AE (20-45\%) in the mussel Mytilus coruscus with no significant differences between three different $\mathrm{pH}$ levels $(8.1,7.7$, and 7.3). Navarro et al. (2013) reported that elevated $\mathrm{pCO}_{2}$ levels ( $\mathrm{pH}$ 7.57) significantly reduced the $\mathrm{AE}$ of Mytilus chilensis, indicating possible deficiencies in the functioning of the digestive system under conditions of seawater acidification. In the present study, Ammonia excretion was affected by acidification, and a decrease 
was observed in clams exposed to the highest $\mathrm{pCO}_{2}$ (1050 ppm; $\left.\mathrm{pH} 7.62\right)$. These results are in consistence with the recorded low clearance rate and low metabolic rate in sequence.

\section{CONCLUSION}

The present study suggests that ongoing ocean acidification may not pose great threats to the exixtence of Mediterranean clam Ruditapes decussatus as many senarios expected. The poor, clearance rate (feeding rate), growth and condition index upon exposure to ocean acidification may lead to poor aquaculture potential and health of $R$. decussatus unless adaptation mechanisms may develop with continuous gradual exposure to increasing ocean acidification. Risk assessment is needed for the Mediterranean bivalve aquaculture in the current century. More research is needed on consequent generations to investigate the possibility of the organisms to create adaptation strategies convenient to future climate scenarios at both organismal and genetic levels.

\section{ACKNOWLEDGMENT}

Special thanks to the National Institute of Oceanography and Fisheries (NIOF) for the provision of facilities, equipments and bench space in laboratories for conducting the current research.

\section{REFERENCES}

Abbas, A.S.A.; El-Wazzan, E.; Khafage, A.R.; El-Sayed, A.M. and Abdel Razek, F.A. (2018). Influence of different microalgal diets on gonadal development of the carpet shell clam Tapes decussatus broodstock. Aquaculture International. 26(5):1297-1309. DOI: https://doi.org/10.1007/s10499-018-0284-9.

Bamber, R. (1987). The effects of acidic sea water on young carpet-shell clams Venerupis decussata (L.) (Mollusca: Veneracea). Journal of Experimental Marine Biology and Ecology. 108(3): 241-260.

Bamber, N.R. (1990). The effects of acidic sea water on three species of lamellibranch molluscs. Journal of Experimental Marine Biology and Ecology. 143(3): 181-191. https://doi.org/10.1016/0022-0981(90)90069-O.

Bayne, B.L. and Newell, R.C. (1983). Physiological energetics of marine molluscs. In The Mollusca. Physiology. 4(1): 407-515.

Beniash, E.; Lieb, N.I.; Kurochkin, I. and Sokolova, I. (2010). Elevated level of carbon dioxide affects metabolism and shell formation in oysters Crassostrea virginica (Gmelin). Marine Ecology Progress Series, 419: 95-108. doi:10.3354/meps08841

Berge, J.A.; Bjerkeng, B.; Pettersen, O. ; Schaanning, M.T., and Oxnevad, S. (2006). Effects of increased seawater concentrations of $\mathrm{CO} 2$ on growth of the bivalve Mytilus edulis L. Chemosphere. 62(4): 681-687. https://doi.org/10.1016/j.chemosphere. 2005.04.111

Bressan, M.; Chinellato, A.; Munari, M.; Matozzo, V.; Manci, A. and Marceta, T. (2014). Does seawater acidification affect survival, growth and shell integrity in bivalve juveniles? Marine Environmental Research 99: 136-148. https://doi.org/10.1594/ PANGAEA. 836888. 
Caldeira, K.; and Wickett, M.E. (2003). Anthropogenic carbon and ocean pH. Nature. 425: 365. doi: 10.1038/425365a.

Catarino, A.I.; De Ridder, C.; Gonzalez, M.; Gallardo, P.and Dubois, P. (2012). Sea urchin Arbacia dufresnei (Blainville 1825) larvae response to ocean acidification. Polar Biology. 35(3): 455-461. doi: 10.1007/s00300-011-1074-2

Caldeira, K. and Wickett, M.E. (2005). Ocean model predictions of chemistry changes from carbon dioxide emissions to the atmosphere and ocean. Journal of Geophysical Research, 110(C9): 1-12. doi:10.1029/2004JC002671.

Cerezo, V. J.; Martínez L. F.J.;and García G. B. (2006). Oxygen consumption and ventilatory frequency responses to gradual hypoxia in common dentex (Dentex dentex): Basis for suitable oxygen level estimations. Aquaculture 256(1-4): 542-551.

Chessa, L.A.; Paesanti, F.; Pais, A.; Scardi, M.; Serra, S.and Vitale, L. (2005). Perspective for development of low impact aquaculture in western Mediterranean lagoon: the case of the carpet clam Tapes decussatus. Aquaculture International 13: 147-155. doi.org/10. 1007/s10499-004-9022-6

Coughlan, J. (1969). The estimation of filtering rate from the clearing of suspension. Marine Biology. 2: 356-358. 10.1007/BF00355716.

Dickson, A.G. and Millero, F.J. (1987). A comparison of the equilibrium constants for the dissociation of carbonic acid in seawater media. Deep Sea Research Part A, Oceanographic Research Papers, 34(10): 1733-1743. Doi:10.1016/01980149(87)90021-5

Dickson, A.G. (1990b). Thermodynamics of the dissociation of boric acid in synthetic seawater from 273.15 to 298.15 K. Deep Sea Research Part A, Oceanographic Research Papers, 37(5): 755-766. Doi: 10.1016/0198-0149(90)90004-F

Dickson, A.G.; Sabine C.L. and Christian, J.R. (2007). Guide to best practices for ocean $\mathrm{CO}_{2}$ measurements. Sidney, British Columbia, North Pacific Marine Science Organization, 176.

Duarte, C.; Navarro, J.M.; Acuna, K.; Torres, R.; Manriquez, P.H.and Lardies, M. A. Vargas, C. A. et al. (2014). Combined effects of temperature and ocean acidification on the juvenile individuals of the mussel Mytilius chilensis. Journal of Sea Research, 85: 308-314.DOI: 10.1016/j.seares.2013.06.002.

Dupont, S.; Dorey, N. and Thorndyke, M. (2010). What meta-analysis can tell us about vulnerability of marine biodiversity to ocean acidification? Estuarine Coastal Shelf Scince.89: 182-185. doi: 10.1016/j.ecss.2010.06.013

El-Wazzan, E.; Abbas, A.S.; Abdel Razek, F.A. and Ragaii, A. (2012). Reproductive Biology of the Carpet Shell Clam, Tapes decussatus, from Egyptian Coastal Waters. Journal of Shellfish Research, 31(1): $279-280$. https://doi.org/10.2983/035.031.0124.

FAO. (2018). The state of world Fisheries and Aquaculture production, Meeting the sustainable development goals, Food and Agriculture Organization of the United Nations, Rome. http://www.fao.org/3/i9540en/I9540EN.pdf

Feely, R.A.; Sabine, C.L.; Lee, K.; Berelson, W.; Kleypas, J.; Fabry, V.J. and Millero, F.J. (2004). Impact of anthropogenic $\mathrm{CO}_{2}$ on the $\mathrm{CaCO}_{3}$ system in the oceans. Science, 305(5682): 362-366. doi:10.1126/science.1097329.

Feely, R.A.; Sabine, C.L.; Byrne, R.H.; Millero, F.J.; Dickson, A.G.; Wanninkhof, R.; Murata, A.; Miler, L.A. and Greeley, D. (2012). Decadal changes in the aragonite and calcite saturation state of the Pacific Ocean, Global Biogeochemical Cycles, 26(3):1-15. doi:10.1029/2011GB004157. 
Fernandez-Reiriz, M.J.; Range, P.; Alvarez-Salgado, X.A. and Labarta, U. (2011). Physiological energetics of juvenile clams Ruditapes decussatus in a high $\mathrm{CO}_{2}$ coastal ocean. Marine Ecology Progress Series, 433: 97-105. doi:10.3354/meps09062

Filgueira, R.; Comeau, L.A.; Landry, T.; Grant, J.; Guyondet, T. and Mallet, A. (2013). Bivalve condition index as an indicator of aquaculture intensity: A meta-analysis. Ecological Indicators, 25: 215-229. https://doi.org/10.1016/j.ecolind.2012.10.001

Fernández-Reiriz, M.; Range, P.; Álvarez-Salgado, X.; Espinosa, J.and Labarta U. (2012). Tolerance of juvenile Mytilus galloprovincialis to experimental seawater acidification. Marine Ecology Progress Series 454: 65-74.

Gazeau, F.; Quiblier, C.; Jansen, J.M.; Gattuso, J.P.; Middelburg, J.J. and Heip, C.H.R. (2007). Impact of elevated $\mathrm{CO}_{2}$ on shellfish calcification. Geophysical Research Letters, 34(7): 1-5. doi:10.1029/2006GL028554

Gazeau, F.; Alliouane, S.; Bock, CH.; Bramanti, L.; López Correa, M.and Gentile, M.; Hirse, T. et al. (2014). Impact of ocean acidification and warming on the Mediterranean mussel (Mytilus galloprovincialis). Frontiers in Marine Science, 62(1): 1-12. doi.org/10.3389/ fmars.2014.00062

Grasshoff, K.; Erhardt, M. and Kremling, K. (1983). Methods of Seawater, Analysis. Verlag Chemi, Weinheim, New York, 419.

Gruber, N.; Hauri, C.; Lachkar, Z.; Loher, D.; Frölicher, T.L. and Plattner, G.K. (2012). Rapid progression of ocean acidification in the California Current System. Science, 337(6091): 220-223. doi:10.1126/science.1216773.

Hönisch, B.; Hemming, N.G.; Archer, D.; Siddall, M. and McManus, J.F. (2009). Atmospheric carbon dioxide concentration across the mid-Pleistocene transition. Science, 324(5934): 1551-1554. doi:10.1126/science.1171477.

Ibrahim, H.A.H.; El-Sayed, W.M.M.; Shaltout, N.A. and El-Shorbagi, E. (2014). Effects of different $\mathrm{pCO}_{2}$ concentrations on marine bacterial community structure, Eastern Harbor, Alexandria, Egypt, Life Science Journal, 11(10), 781 789. http://www. lifesciencesite. com.126

Khairy, H.M.; Shaltout, N.A.; El-Naggar, M.F. and El-Naggar, N.A. (2014). Impact of Elevated $\mathrm{CO}_{2}$ Concentrations on the Growth and Ultrastructure of Noncalcifying Marine Diatom (Chaetoceros gracilis F.Schütt), The Egyptian Journal of Aquatic Research, 40 (3): 243-250.

Lewis, E. and Wallace, D.W.R. (1998). Program developed for $\mathrm{CO}_{2}$ system calculations, Carbon Dioxide Information Analysis Center, Report ORNL/CDIAC-105, Oak Ridge National Laboratory Environmental Sciences Division, v. 4735, U.S. Department of Energy, Oak Ridge, Tennessee.

Lucrezia, C.; Tommaso, S.; Antonietta, S.; Marisa, F. andPaolo, B. (2011). Bio indicators for siting the carpet clam Tapes decussatus L. farming in Mediterranean lagoons. International Journal of Fisheries and Aquaculture. 3(3): 53-63. Doi: http://www. academicjournals.org/IJFA

Mehrbach, C.; Culberson, C.H.; Hawley, J.E. and Pytkowicz, R.N. (1973). Measurement of the apparent dissociation constants of carbonic acid in seawater at atmospheric pressure. Limnology and Oceanography 18: 897-907. https://doi.org/10.4319/lo.1973.18.6.0897.

Melzner, F.; Stange, P.; Trübenbach, K.; Thomsen, J.; Casties, I.; Panknin, U.and Gorb, S.N. et al. (2011). Food Supply and seawater $\mathrm{pCO}_{2}$ impact calcification and internal shell dissolution in the blue mussel Mytilus edulis. PLoS One 6 (9): 1-9. https://doi.org/10. 1371/journal. pone.0024223 
Melatunan, S.; Calosi, P.; Rundle, S.; Widdicombe, S.andMoody, A. (2013). Effects of ocean acidification and elevated temperature on shell plasticity and its energetic basis in an intertidal gastropod. Mar. Ecol. Prog. Ser. 472: 155-168.

Michaelidis, B.; Ouzounis, C.; Paleras, A. and Pörtner, H.O. (2005). Effects of longterm moderate hypercapnia on acid - base balance and growth rate in marine mussels Mytilus galloprovincialis. Marine Ecology Progress Series, 293: 109118. Doi: $10.3354 /$ meps293109.

Navarro, J.M.; Torres, R.; Acuna, K.; Duarte, C.; Manriquez, P.H.; Lardies, M.; Lagos, N.A., et al. (2013). Impact of medium-term exposure to elevated $\mathrm{pCO}_{2}$ levels on the physiological energetic of the mussel Mytilus chilensis. Chemosphere, 90(3): 1242-1248. https://doi.org/ 10.1016/j.chemosphere.2012.09.063.

Orr, J.C. (2005). Anthropogenic ocean acidification over the twenty-first century and its impact on calcifying organisms. Nature 437: 681-686.

Pan, T.C.F.; Applebaum, S.L. and Manahan, D.T. (2015). Experimental ocean acidification alters the allocation of metabolic energy. Proceedings of the National Academy of Sci., 112(15): 4696-4701. https://doi.org/10.1073/pnas.1416967112.

Pörtner, H.O., and Farrel, A.P. (2008). Physiology and climate change. Science, 322(5902): 690-692. DOI: 10.1126/science.1163156.

Prado-Alvarez, M.; Gestal, C.; Novoa, B. and Figueras, A. (2009). Differentially expressed genes of the carpet shell clam Ruditapes decussatus against Perkinsus olseni. Fish and Shellfish Immunology 26: 72-83. doi.org/10.1016/j.fsi.2008.03.002.

Range, P.; Chícharo, M.A.; Ben-Hamadou, R.; Piló, D.; Matias, D.; Joaquim, S.; Oliveira, A.P. et al. (2011). Calcification, growth and mortality of juvenile clams Ruditapes decussatus under increased $\mathrm{pCO}_{2}$ and reduced $\mathrm{pH}$ : variable responses to ocean acidification at local scales? Journal of Experimental Marine Biology and Ecology. 396(2): 177-184. https://doi.org/10.1016/j.jembe.2010.10.020.

Ringwood, A.H. and C.J. Keppler. (2002). Water quality variation and clam growth: is $\mathrm{pH}$ really a non-issue in estuaries? Estuaries. 25(5): 901-907. https://doi. org/10. 1007/ BF02691338.

Sarazin, G.; Michard, G. and Prevot, F. (1999). A rapid and accurate spectroscopic method for alkalinity measurements in sea water samples. Water Research. 33(1): 290-294. https://doi.org/10.1016/S0043-1354(98)00168-7.

Stumpp, M.; Wren, J.; Melzner, F.; Thorndyke, M.C.and Dupont, S.T. (2011). $\mathrm{CO}_{2}$ induced seawater acidification impacts sea urchin larval development $\mathrm{I}$ : Elevated metabolic rates decrease scope for growth and induce developmental delay. Comparative Biochemistry and Physiology Part A: Molecular and Integrative Physiology. 160(3): 331-340. https://doi.org/ 10.1016/j.cbpa.2011.06.022.

Shirayama, Y. and Thornton, H. (2005). Effect of increased atmospheric $\mathrm{CO}_{2}$ on shallow water marine benthos. Journal of Geophysical Research, 10(C09S08): 1-7. doi:10.1029/2004JC002618.

Talmage, W.C. and Gobler, C.J. (2011). Effects of elevated temperature and carbon dioxide on the growth and survival of larvae and juveniles of three species of Northwest Atlantic bivalves. PLoS ONE, 6(10): 1-12 https://doi.org/10.1371/ journal.pone.0026941.

Thomsen, J. and Melzner, F. (2010). Moderate seawater acidification does not elicit long-term metabolic depression in the blue mussel Mytilus edulis. Marine Biology.Volume 157(12): 2667-2676. https://doi.org/10.1007/s00227-0101527-0. 
Thomsen, J.; Casties, I.; Pansch, C.; Körtzinger, A. and Melzner, F. (2013). Food availability outweighs ocean acidification effects in juvenile Mytilus edulis: laboratory and field experiments. Global Change Biology, 19(4):1017-1027. doi:10.1111/gcb.12109

Van Heuven, S.M.A.C.; Hoppema, M.; Huhn, O.; Slagter, H.A. and de Baar, H.J.W. (2011b). Direct observation of increasing $\mathrm{CO}_{2}$ in the Weddell Gyre along the Prime Meridian during 19732008, Deep Sea Research Part II: Topical Studies in Oceanography, 58 (2526): 2613-2635, doi: 10.1016/j.dsr2.2011.08.007.

Velasco, L.A. and Navarro, J.M. (2005). Feeding physiology of two bivalves under laboratory and field conditions in response to variable food concentrations. Marine Ecology Progress Series, 291: 115-124. doi:10.3354/meps291115.

Walne, P.R. (1976). Experiments on the culture in the sea of the butterfish Venerupis decussata L. Aquaculture 8: 371-381. doi.org/10.1016/0044-8486(76)90119-8.

Wang, Y.; Li, L.; Hu, M. and Lu, W. (2015). Physiological energetic of the thick shell mussel Mytilus coruscus exposed to seawater acidification and thermal stress. Science of the Total Environment, 1: 261-272. doi: 10.1016/j. scitotenv. 2015.01.092.

Wood, H.L.; Spicer, J.I. andWiddicombe, S. (2008). Ocean acidification may increase calcification rates, but at a cost. Proceedings of the Royal Society B: Biological Sciences, 275(1644): 1767-1773. http://doi.org/10.1098/rspb.2008.0343. 